\title{
UJI AKTIVITAS ANTIMIKROBA EKSTRAK DIETIL ETER AKAR ANTING-ANTING (Acalypha australis L.) SECARA KLT-BIOAUTOGRAFI
}

\author{
A. Mumtihanah Mursyid \\ Fakultas Farmasi Universitas Muslim Indonesia \\ Email : mumtihanah@gmail.com
}

\begin{abstract}
A research had been done of antimicrobial activity of Anting-anting (Acalypha australis L.). The preliminary research was done by screening test using Staphylococcus aureus, Salmonella typhi, Streptococcus mutans, Staphylococcus epidermidis, Pseudomonas aeroginosa, Escherichia coli, Vibrio sp, Bacillus subtilis and Candida albicans toward extract of ethanol, dietyl eter and n-butanol of antinganting (Acalypha australis L.) wich were use in $1 \mathrm{mg} / \mathrm{ml}$. The result showed that the dietil eter extract inhibit growth of bacteria, Staphylococcus aureus, Escherichia coli, Bacillus subtilis and Salmonella typhi. The test Antimicrobial activity toward dietil eter extract of Gamal (Glyricidia sepium (Jacq).Steud.) was done by using the liquid dilution methode to find out the MIC value in concentration $0,00625 \%, 0,025 \%$, $0,1 \%, 0,4 \%$ and $1,6 \%$ continued by spreading on solid medium to find out the MKC value. The result showed that MIC toward to Staphylococcus aureus is 0,025\%, Eschericia coli is 0,1\%, Bacillus subtilis is 0,025\%, and Salmonella thypii is $0,025 \%$. While MKC toward to Staphylococcus aureus is 1,6\%, Escherichia coli is 0,4\%, Bacillus subtilis is $0,025 \%$, and Salmonella thypii is $0,1 \%$. The TLC-Bioautography technique was used to predict the active constituents. The best result has been obtained from separating by means TLC which used mixture of $n$-hexane : ethyl acetate (3:1). The result of TLC-Bioautografi showed that the spot in $R f$ 0,27 and $R f$ 0,36 given the activity antimkrobial toward Escherchia coli, Rf 0,36 toward Bacillus subtilis, and Rf 0,45 toward Staphylococcus aureus and Salmonella typhi. The identification result of the chemical component shown that the actif compound wich given positif result as fenol on spot in Rf 0,27 and 0,36 and the active compound wich given positif result as steroid on spot in Rf 0,45.
\end{abstract}

Key word : Aktivitas antimikroba, Skrining, KLT-Bioautografi, Anting-anting (Acalypha australis L.)

\section{PENDAHULUAN}

Tumbuhan anting-anting
(Acalypha australis Linn.) yang
merupakan suku Euphorbiaceae
merupakan gulma yang sangat umum
ditemukan tumbuh liar di pinggir jalan,

lapangan rumput, maupun di lereng gunung yang berupa herba dengan tinggi $30-50 \mathrm{~cm}$. Tumbuhan ini memiliki rasa yang pahit. Pada akar, batang, dan daun mengandung saponin dan tannin. Batang juga 
mengandung flavanoid dan daunnya mengandung minyak atsiri (Dalimartha, 2000). Herba antinganting berkhasiat mengobati disentri basiler, disentri amuba, diare, anak dengan berat badan rendah (malnutrition), dan gangguan pencernaan. Muntah darah, mimisan, berak darah (melena), kencing darah (hematuria). (Hariana, 2005) Secara empiris digunakan oleh masyarakat di Kabupaten Bone sebagai obat disentri. Namun kebenaran efektivitasnya sebagai antimikroba belum dibuktikan secara ilmiah. Sehingga untuk menguji kebenarannya, maka penelitian ini dilakukan dengan menguji ekstrak akar anting-anting (Acalypha australis L.) terhadap beberapa mikroba uji tertentu agar penggunaannya dalam masyarakat dapat dipertanggung jawabkan.

\section{METODE PENELITIAN}

\section{A. Pengolahan dan ekstraksi sampel}

Sampel akar anting-anting dicuci bersih dengan air mengalir kemudian dipotong-potong kecil dan dikeringkan dengan cara diangin-anginkan dan tidak terkena sinar matahari langsung. Akar anting-anting yang telah dikeringkan ditimbang sebanyak
900 gram kemudian dimasukkan ke dalam labu alas bulat dan ditambahkan metanol sampai serbuk simplisia terendam kurang lebih $2 \mathrm{~cm}$ diatas permukaan simplisia, atau 2/3 dari volume labu kemudian labu alas bulat dipasang kuat pada statif pada waterbath atau heating mantel lalu kondensor dipasang pada labu alas bulat yang dikuatkan dengan klem dan statif. Aliran air dan pemanas (waterbath) dijalankan sesuai dengan suhu pelarut yang digunakan. Setelah 4 jam dilakukan penyaringan filtratnya ditampung dalam wadah penampung dan ampasnya ditambah lagi pelarut dan dikerjakan seperti semula, ekstraksi dilakukan sebanyak 3-4 kali. Pengerjaan ini dilakukan sebanyak 3 kali. Hasil penyarian yang didapat kemudian dikumpulkan dan diuapkan dengan menggunakan rotavapor hingga diperoleh ekstrak metanol yang kental sebanyak 7 gram. Sebagian dari ekstrak tersebut dipisahkan untuk dibuat sediaan uji sesuai dengan jumlah yang akan dibuat.

\section{B. Partisi dengan dietil eter}

Ekstrak metanol kental yang telah diperoleh ditimbang sebanyak 6 gram kemudian disuspensikan 
dengan air sebanyak $15 \mathrm{ml}$, kemudian dimasukkan dalam corong pisah dan diekstraksi dengan dietil eter sebanyak $30 \mathrm{ml}$, sambil dikocok dengan tutup corong pisah dibuka agar tekanan di dalam corong pisah tidak lebih tinggi lalu didiamkan beberapa saat sampai lapisan air dan dietil eter terpisah dimana lapisan dietil eter terdapat di bagian atas dan air di bagian bawah kemudian dipisahkan lapisan air dengan ekstrak dietil eternya. Kemudian lapisan air diekstraksi lagi dengan dietil eter sebanyak $30 \mathrm{ml}$ dan dilakukan hingga jernih. Kemudian ekstrak dietil eter dikumpulkan dan diuapkan hingga diperoleh ekstrak kental dietil eter sebanyak 2,4 gram kemudian dikeringkan dalam eksikator. Sebagian dari ekstrak tersebut dipisahkan untuk dibuat sediaan uji sesuai dengan jumlah yang akan dibuat.

\section{Partisi dengan n-butanol}

Lapisan air yang diperoleh dari ekstraksi eter dimasukkan dalam corong pisah, kemudian diekstraksi dengan n-butanol jenuh air sebanyak $30 \mathrm{ml}$ setelah didiamkan beberapa saat akan terpisah antara lapisan air dengan n-butanol jenuh air. Lapisan n-butanol diuapkan sehingga diperoleh ekstrak kental n-butanol sebanyak 3,2 gram dan dikeringkan di dalam eksikator.

D. Penyiapan mikroba uji

\section{Peremajaan mikroba uji}

Bakteri/jamur diambil dari biakan murni masing-masing satu ose kemudian diinokulasikan pada medium NA miring dengan cara digoreskan secara aseptis. Masing-masing biakan bakteri diinkubasi selama 1 x 24 jam pada suhu $37^{0} \quad \mathrm{C}$ sedangkan jamur diinkubasi selama $3 \times 24$ jam pada suhu $27^{0} \mathrm{C}$.

2. Pembuatan suspensi mikroba uji

Kultur bakteri umur $1 \mathrm{x}$ 24 jam dan jamur umur $3 \times 24$ jam yang telah diremajakan dalam medium GNA miring disuspensikan dengan $\mathrm{NaCl}$ fisiologis ( $\mathrm{NaCl}$ 0,9\%) kemudian diukur kekeruhannya $25 \% \mathrm{~T}$ untuk bakteri dan $75 \%$ T untuk jamur.

\section{E. Pengujian ekstrak}

\section{Skrining antimikroba}

Sebanyak $10 \mathrm{mg}$ ekstrak etanol kental, ekstrak dietileter, dan ekstrak n-butanol sampel daun gamal ditimbang lalu dimasukkan ke dalam vial 
steril dan dilarutkan dalam 200

$\mu \mathrm{l}$ DMSO $(200 \mu \mathrm{l}=0,2 \mathrm{ml})$ dengan menggunakan mikropipet, kemudian dicampurkan dengan $9,8 \mathrm{ml}$ GNA yang telah dicairkan dengan konsentrasi $1 \mathrm{mg} / \mathrm{ml}$ media hingga volume akhir 10 $\mathrm{ml}$. Campuran tersebut dituang ke dalam cawan petri steril dan dibiarkan memadat. Setelah memadat ditambahkan $20 \mu \mathrm{l}$ suspensi mikroba uji. Setiap cawan petri dibagi menjadi dua zona untuk masing-masing mikroba uji. Kemudian diinkubasikan pada suhu $37^{\circ} \mathrm{C}$ selama $1 \times 24$ jam untuk bakteri dan $27^{\circ} \mathrm{C}$ selama $3 \times 24$ jam untuk jamur. Suatu sampel digolongkan memiliki aktivitas antimikroba jika tidak ada pertumbuhan mikroba yang terjadi pada media.

\section{Uji Konsentrasi Hambat} Minimum (KHM)

Uji penentuan harga KHM dilakukan dengan cara membuat beberapa seri konsentrasi sampel $0,025 \%$, $0,05 \%, \quad 0,1 \%, \quad 0,2 \%, \quad 0,4 \%$, $0,8 \%$ dan $1,6 \%$ dalam tabung reaksi yang berisi $5 \mathrm{ml}$ medium
NB kemudian dimasukkan mikroba uji. Diinkubasi pada suhu $37^{\circ} \mathrm{C}$ selama 24 jam untuk melihat ada tidaknya pertumbuhan mikroba. Konsentrasi terendah sampel yang aktif, dimana larutan tampak jernih setelah inkubasi, menunjukan harga KHM.

\section{Uji Konsentrasi Bunuh Minimum (KBM)}

Hasil inkubasi pada uji KHM kemudian digoreskan pada media GNA, lalu diinkubasikan pada suhu $37^{\circ} \mathrm{C}$ selama 24 jam (bakteri) dan $27^{\circ} \mathrm{C}$ selama 72 jam (jamur). Konsentrasi terendah sampel yang aktif yang bersifat antimikroba dimana apabila hasilnya berupa daerah tanpa pertumbuhan setelah inkubasi, menunjukan harga KBM.

4. Pemisahan senyawa secara Kromatografi Lapis Tipis (KLT)

Lempeng KLT sebelum digunakan diaktifkan terlebih dahulu dengan pemanasan dalam oven pada suhu $100^{\circ} \mathrm{C}$ selama 30 menit. Ekstrak eter ditotolkan pada lempeng KLT ukuran $7 \times 1 \mathrm{~cm}$ menggunakan 
pipa kapiler. Kemudian dielusi dengan menggunakan eluen dengan perbandingan tertentu didalam chamber. Lempeng dikeluarkan dari chamber dan diangin-anginkan hingga eluennya menguap. Kemudian kromatogram yang dihasilkan diamati nodanya dibawah sinar UV pada panjang gelombang 254 dan 366 nm.

5. Pengujian secara KLTBioautografi

Hasil identifikasi KLT dengan eluen yang terbaik dilanjutkan dengan uji KLTBioautografi kontak dengan cara media GNA steril sebanyak $10 \mathrm{ml}$ dituang ke dalam cawan petri steril, lempeng KLT yang telah dielusi dengan eluen yang sesuai diletakkan di atas permukaan medium agar yang telah diinokulasi dengan mikroba uji dan dibiarkan selama 60 menit, kemudian lempeng tersebut diangkat dan dikeluarkan. Selanjutnya medium diinkubasi pada suhu $37^{\circ} \mathrm{C}$ selama 24 jam. Kemudian diamati zona hambatan yang terbentuk.

\section{HASIL PENELITIAN}

Tabel 1. Hasil Ekstraksi Sampel akar anting-anting (Acalypha australis L.)

\begin{tabular}{clc}
\hline No. & \multicolumn{1}{c}{ Sampel } & Bobot (gram) \\
\hline 1. & Akar anting-anting & 450 \\
2. & Ekstrak metanol & 30,20 \\
3. & Ekstrak metanol yang diekstraksi & 20,00 \\
4. & Ekstrak dietil eter & 11,30 \\
5. & Ekstrak n-butanol & 3,70 \\
\hline
\end{tabular}

Tabel 2. Hasil Skrining Aktivitas Antimikroba Ekstrak akar anting-anting (Acalypha australis L.) Terhadap Mikroba Uji

\begin{tabular}{ccccccccccc}
\hline \multirow{2}{*}{ No } & \multirow{2}{*}{ Sampel } & \multicolumn{10}{c}{ Mikroba Uji } \\
\cline { 3 - 10 } & & Vsp & ST & SM PA & EC & BS & SE & SA & CA \\
\hline 1. & Ekstrak methanol & - & - & - & - & + & - & + & - & - \\
2. & Ekstrak dietil eter & - & + & - & - & + & + & - & + & - \\
3. & Ekstrak n-Butanol & - & - & - & + & - & + & - & - & - \\
4. & K+ Bakteri & + & + & + & + & + & + & + & + & $\#$ \\
5. & K+ Jamur & $\#$ & $\#$ & $\#$ & $\#$ & $\#$ & $\#$ & $\#$ & $\#$ & + \\
6. & K - DMSO & - & - & - & - & - & - & - & - & - \\
\hline
\end{tabular}




\section{Pengujian Kadar Hambat Minimum (KHM)}

Penentuan nilai KHM yang mana pada penelitian ini menemui kendala berupa larutan uji yang keruh, akibat ekstrak yang terlarut, sedangkan utuk melihat ada tidaknya pertumbuhan mikroba ditunjukkan dengan tingkat kekeruhan larutan uji. Dengan demikian nilai KHM ekstrak dietil eter daun gamal tidak dapat ditentukan. Karena itu pengujian dilanjutkan dengan Pengujian Kadar Bunuh Maksimum (KBM).

Tabel 3. Hasil uji Konsentrasi Hambat Minimum (KHM) ekstrak dietil eter akar anting-anting (Acalypha australis L.)

\begin{tabular}{lccccccc}
\hline \multirow{2}{*}{ Bakteri } & \multicolumn{9}{c}{ Konsentrasi (\%) } & \multirow{2}{*}{ KS } & KM \\
\cline { 2 - 7 } & $\mathbf{0 , 0 0 6 2 5}$ & $\mathbf{0 , 0 2 5}$ & $\mathbf{0 , 1}$ & $\mathbf{0 , 4}$ & $\mathbf{1 , 6}$ & & - \\
\hline Staphylococcus aureus & + & - & - & - & - & - & - \\
Escherichia coli & + & + & - & - & - & - & - \\
Bacillus subtilis & + & - & - & - & - & - & - \\
Salmonella typhii & + & - & - & - & - & - & - \\
\hline
\end{tabular}

Tabel 4. Hasil uji Konsentrasi Bunuh Minimum (KBM) ekstrak dietil eter akar antinganting (Acalypha australis L.)

\begin{tabular}{lccccccc}
\hline \multirow{2}{*}{ Bakteri } & \multicolumn{9}{c}{ Konsentrasi (\%) } & \multirow{2}{*}{ KS } & KM \\
\cline { 2 - 7 } & $\mathbf{0 , 0 0 6 2 5}$ & $\mathbf{0 , 0 2 5}$ & $\mathbf{0 , 1}$ & $\mathbf{0 , 4}$ & $\mathbf{1 , 6}$ & & - \\
\hline Staphylococcus aureus & + & + & + & + & - & - & - \\
Escherichia coli & + & + & + & - & - & - & - \\
Bacillus subtilis & + & - & - & - & - & - & - \\
Salmonella typhii & + & + & - & - & - & - & - \\
\hline
\end{tabular}

Tabel 5. Hasil Profil KLT ekstrak dietil eter akar anting-anting (Acalypha australis L.)

\begin{tabular}{|c|c|c|c|c|c|c|}
\hline \multirow{3}{*}{$\begin{array}{l}\text { Jumlah } \\
\text { Bercak }\end{array}$} & \multicolumn{6}{|c|}{ Penampak bercak pada } \\
\hline & \multicolumn{2}{|c|}{ UV 254} & \multicolumn{2}{|c|}{ UV 366} & \multicolumn{2}{|c|}{$\mathrm{H}_{2} \mathrm{SO}_{4} \mathbf{1 0} \%$} \\
\hline & $\mathbf{R f}$ & Warna & $\mathbf{R f}$ & Warna & Rf & Warna \\
\hline 1 & 0,73 & Biru & 1 & Berpendar & 1 & Merah \\
\hline 2 & 0,64 & Hijau tua & 0,9 & Berpendar & 0,87 & Kuning \\
\hline 3 & 0,45 & Hijau muda & 0,73 & Üngu & 0,9 & Ungu \\
\hline 4 & 0,36 & Hijau muda & 0,64 & Ungu & 0,75 & Kuning \\
\hline 5 & 0,27 & Biru & 0,45 & Ungu & 0,72 & Ungu \\
\hline 6 & 0,18 & Hijau muda & 0,36 & Ungu & 0,64 & Hijau \\
\hline 7 & - & - & 0,27 & Ungu & 0,45 & Ungu \\
\hline 8 & - & - & 0,18 & Berpendar & 0,36 & Ungu \\
\hline 9 & - & - & - & - & 0,27 & Ungu \\
\hline 10 & - & - & - & - & 0,18 & Merah muda \\
\hline
\end{tabular}


Tabel 6. Hasil Identifikasi ekstrak dietil eter akar anting-anting (Acalypha australis L.)

\begin{tabular}{cccccc}
\hline \multirow{2}{*}{ Bercak } & \multirow{2}{*}{$\mathbf{R f}$} & \multicolumn{2}{c}{ Warna Pada Penampak Bercak } & \multirow{2}{*}{$\begin{array}{c}\text { Aktif Terhadap } \\
\text { Bakteri Uji }\end{array}$} \\
\cline { 3 - 5 } & & UV 254 & UV 366 & $\mathrm{H}_{2} \mathrm{SO}_{4}$ & Bakn \\
2 & 0,454 & Hijau muda & Ungu & Ungu & SA \& ST \\
3 & 0,363 & Hijau muda & Ungu & Ungu & BS \& EC \\
\hline 0,272 & Ungu & Berpendar & Merah muda & EC \\
\hline
\end{tabular}

Tabel 7. Hasil Pengujian Identifikasi Komponen Kimia Aktif dari Kromatogram ekstrak dietil eter akar anting-anting (Acalypha australis L.)

\begin{tabular}{ccccc}
\hline Bercak & Pereaksi & Rf & Warna & Ket. \\
\hline 1 & Besi (III) klorida & 0,45 & Hijau & Fenol \\
1 & Perak nitrat & 0,45 & Hijau & Fenol \\
2 & Besi (III) klorida & 0,36 & Hijau & Fenol \\
2 & Perak nitrat & 0,36 & Hijau & Fenol \\
3 & Vanilin asam sulfat & 0,27 & Ungu & Steroid \\
3 & Liebermann buchard & 0,27 & Berpendar & Steroid \\
3 & Asam fosfat & 0,27 & Berpendar & Steroid \\
\hline
\end{tabular}

\section{PEMBAHASAN}

Akar Anting-anting (Acalypha australis Linn.) diekstraksi dengan menggunakan metode refluks karena sampel termasuk tekstur kasar dengan pelarut metanol yang memiliki sifat semipolar yang berarti dapat menyari komponen kimia baik polar maupun nonpolar. Cairan penyari akan menembus dinding sel dan masuk ke dalam rongga sel yang mengandung zat aktif. Zat aktif akan larut dalam penyari karena adanya perbedaan konsentrasi antara larutan di dalam dan di luar sel, sehingga larutan yang terpekat di desak keluar. Ekstrak metanol disaring dan diuapkan dengan menggunakan rotavapor hingga diperoleh ekstrak kental. Selanjutnya dipartisi dengan menggunakan pelarut dietil eter dan n-butanol. Proses partisi pertama menggunakan pelarut dietil eter yang kepolarannya lebih rendah dibandingkan n-butanol. Hal ini betujuan agar senyawa-senyawa yang kepolarannya lebih rendah dapat ikut terekstraksi. Digunakan 3 variasi ekstrak agar dapat membandingkan ekstrak yang lebih efektif dalam menghambat pertumbuhan mikroba uji. Hasil uji skrining aktivitas antimikroba menunjukkan bahwa ekstrak metanol dengan konsentrasi 1 $\mathrm{mg} / \mathrm{ml}$ mempunyai hambatan pertumbuhan mikroba yang aktif terhadap Escherichia coli dan Staphylococcus epidermidis.

Sedangkan untuk ekstrak dietil eter dengan konsentrasi $1 \mathrm{mg} / \mathrm{ml}$ mempunyai hambatan pertumbuhan mikroba yang aktif terhadap bakteri Staphylococcus aureus, Escherichia 
coli, Bacillus subtilis dan Salmonella typhi. Untuk ekstrak n-butanol dengan konsentrasi $1 \mathrm{mg} / \mathrm{ml}$ mempunyai hambatan pertumbuhan mikroba yang aktif terhadap Pseudomonas aeruginosa dan Bacillus subtilis. Berdasarkan seluruh hasil pengujian skrinning yang diperoleh, terlihat bahwa ekstrak dietil eter yang paling potensial untuk diteliti lebih lanjut daya antimikrobanya. Pada hasil kontrol negatif, dimana DMSO dengan konsentrasi $0,2 \mathrm{ml}$ sebagai pelarut ekstrak, tidak menunjukkan aktivitas penghambatan mikroba, hal ini membuktikan bahwa memang hanya ekstrak yang memberikan hambatan mikroba.

\section{Perbedaan hasil skrining} ekstrak metanol, dietil eter dan $\mathrm{n}$ butanol terhadap mikroba uji disebabkan komponen kimia yang memiliki kepolaran rendah sehingga akan tersari ke ekstrak dietil eter. Sedangkan ekstrak metanol yang mengandung komponen polar dan non polar kurang memberikan aktivitas antimikroba karena dimungkinkan adanya interaksi komponen kimia yang polar dengan non polar sehingga mengurangi atau menghilangkan efek antimikrobanya serta dimungkinkan kadar komponen non polar yang aktif sebagai antimikroba lebih sedikit pada ekstrak etanol dibandingkan ekstrak dietil eter dengan kadar yang sama. Pada ekstrak n-butanol komponen kimia yang tersari adalah yang bersifat polar sedangkan yang aktif adalah komponen kimia non polar.

Setelah pengujian skrining, kemudian dilanjutkan dengan penentuan nilai KHM. Proses pengujian KHM. Dari hasil penentuan nilai KHM diperoleh kadar hambat yang bervariasi untuk masing-masing mikroba uji, yaitu pada bakteri uji Staphylococcus aureus diperoleh nilai KHM 0,025\%, pada bakteri uji Escherichia colii diperoleh nilai KHM $0,1 \%$, pada bakteri uji Bacillus subtilis

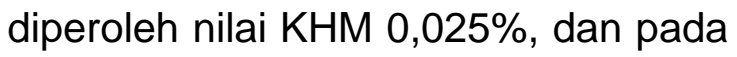
bakteri uji Salmonella thypii diperoleh nilai KHM 0,025\%. Pengujian KHM kemudian dilanjutkan pada uji KBM, dengan menggoreskan konsentrasi KHM, yaitu $0,0625 \% ; 0,025 \% ; 0,1 \%$; $0,4 \%$; dan $1,6 \%$ pada medium agar untuk Staphylococcus aureus, Escherichia coli, Bacillus subtilis dan Salmonella typhi. Berdasarkan hasil pengujian tersebut maka diperoleh nilai KBM untuk Staphylococcus aureus adalah 1,6\%,untuk Escherichia coli adalah $0,4 \%$, untuk Bacillus subtilis adalah $0,025 \%$, dan untuk Salmonella typhi adalah $0,1 \%$. 
Untuk mengetahui senyawa yang memberikan aktivitas antimikroba dari ekstrak dietil eter akar antinganting (Acalypha australis L.), maka pengujian dilanjutkan dengan metode KLT-Bioautografi yaitu metode kontak. Berdasarkan hasil KLT bioautografi tersebut, menunjukkan bahwa bercak pada nilai $\operatorname{Rf} \quad 0,27$ dan $\operatorname{Rf} \quad 0,36$ memberikan aktivitas antimikroba terhadap Escherichia coli, Rf 0,36 memberikan aktivitas antimikroba terhadap Basillus subtilis, dan Rf 0,45 memberikan aktivitas antimikroba terhadap Staphylococcus aureus dan Salmonella typhi yang ditandai dengan adanya zona bening pada permukaan medium tempat berdifusi bercak tersebut.

Terbentuknya zona bening pada permukaan medium tempat berdifusi bercak dari ekstrak dietil eter akar anting-anting (Acalypha australis L.) terhadap Staphylococcus aureus, Escherichia coli, Bacillus subtilis dan Salmonella typhi dapat disebabkan adanya senyawa antimikroba yang terdapat dalam ekstrak tersebut.

Setelah dilakukan identifikasi komponen kimia dengan menggunakan pereaksi penampak bercak dapat diketahui bahwa pada ekstrak dietil eter akar anting-anting (Acalypha australis L.) terdapat satu komponen kimia yaitu fenol dan steroid. Komponen kimia fenol diidentifikasi dengan menggunakan penampak bercak $\mathrm{FeCl}_{3}$ dan perak nitrat memberikan hasil yang positif pada bercak dengan nilai $\operatorname{Rf} 0,36$ dan 0,45 . Sedangkan untuk steroid diidentifikasi dengan menggunakan penampak bercak vanilin asam sulfat, liebermann, dan asam fosfat memberikan hasil yang positif pada bercak dengan nilai Rf 0,27.

\section{KESIMPULAN}

1. Ekstrak dietil eter daun akar anting-anting (Acalypha australis L.) memberikan aktivitas antimikroba terhadap bakteri Staphylococcus aureus, Escherichia coli, Bacillus subtilus, dan Salmonella typhi.

2. Bercak aktif ekstrak dietil eter yang memberikan aktivitas antimikroba, memberikan hasil positif terhadap penampak bercak golongan fenol dan steroid.

\section{DAFTAR PUSTAKA}

Dalimartha,S., 2003, Atlas Tumbuhan Obat Indonesia, Jilid 3, Puspa Swara, Jakarta

Direktorat Jendral POM, 1986, Sediaan Galenik, Jakarta, Departemen Kesehatan Republik Indonesia.

Djide, M.N., 2003, Analisis Mikrobiologi Farmasi, 
Laboratorium Mikrobiologi dan Bioteknologi, Fakultas MIPA, Universitas Hasanuddin, Makassar.

Djide, M.N., 2005, Mikrobiologi Farmasi Terapan, Laboratorium Mikrobiologi dan Bioteknologi Farmasi, Fakultas MIPA, Universitas Hasanuddin, Makassar.

Ganiswarna, G.S.,2007, Farmakologi dan Terapi, Edisi 5, Bagian Farmakologi Fakultas Kedokteran, Universitas Indonesia, Jakarta,586.

Gritter, R.j., Schwerting, A.E, 1991. Pengantar Kromatografi, Edisi kedua, Terjemahan Kosasih panwawinata, Penerbit ITB, Bandung hal. 1,14, 114-115.

Hariana, A., 2005, "Tumbuhan Obat dan Khasiatnya", Seri Agrisehat 1, Penebar Swadaya, Jakarta.

Heyne, K., 1987, "Tumbuhan Berguna Indonesia", Jilid 2, Yayasan Sarana Wana, Jakarta.

Holt, J,G., 1994, Bergey's Manual of Determinative Bacteriology, $9^{\text {th }}$ Edition, The Williams Wilkins
Company, Baltimore, Maryland 21202 United States of America.

Lay,B,W., 1994, Analisa Mikroba Di Laboratorium, PT., Raja Grafindo Persada, Jakarta.

Mycek, M.J., 2001, Farmakologi Ulasan Bergambar, Cetakan 1, terjemahan Azwar Agoes, Widya Media, Jakarta.

Pelczar, M, J., 1988, Dasar-dasar Mikrobiologi, Penerjemah R.S. Hadiotomo dkk, Ui-Press, Jakarta.

Sastroamidjojo, H, 1985. Kromatografi, Liberty, Yogyakarta.

Tobo, F., Mufidah, Taebe, B dan Mahmud, I., 2001, Buku Pegangan Laboratorium Fitokimia I ( Ekstraksi Komponen Kimia Bahan Alam), Laboratorium Fitokimia Jurusan Farmasi, FMIPA, Universitas Hasanuddin, Makassar.

Waluyo, L., 2008, Teknik dan Metode Dasar dalam Mikrobiologi, Universitas Muhammadiyah Malang. 